\title{
The Relationship of Self-Efficacy with Adherence in Restricting Fluid Intake in Middle Adult Hemodialysis Patients
}

\author{
$1^{\text {st }} \mathrm{N}$ Gartika \\ Medical Surgical Nursing Department \\ Sekolah Tinggi Ilmu Kesehatan \\ 'Aisyiyah Bandung \\ Jl.K.H. Ahmad Dahlan Dalam No. 6, \\ Bandung, Indonesia \\ nina.gartika@gmail.com
}

\author{
$2^{\text {nd }}$ A Mustopa \\ Student, Undergraduate Study \\ Program, Sekolah Tinggi Ilmu \\ Kesehatan 'Aisyiyah Bandung \\ Jl.K.H. Ahmad Dahlan Dalam No. 6, \\ Bandung, Indonesia
}

\author{
$3^{\text {rd }}$ A Fatmawati \\ Maternity Nursing Department \\ Sekolah Tinggi Ilmu Kesehatan \\ 'Aisyiyah Bandung \\ Jl.K.H. Ahmad Dahlan Dalam No. 6, \\ Bandung, Indonesia
}

\begin{abstract}
An indicator of the success of ESRD (EndStage Renal Disease) patients undergoing hemodialysis is adherence to fluid intake restrictions. Several studies showed that one of the factors related to the adherence of fluid restriction is self-efficacy, but the study about this adherence in middle-aged still limitation.The purpose of this study was to identify the relationship between self-efficacy and fluid intake restriction on adult hemodialysis patients in Al-Islam Hospital Bandung. This study used a quantitative method with a cross-sectional design, with 48 respondents recruited by purposive sampling. Collecting data was conducted by questionnaires about self-efficacy and fluid intake restriction adherence on ESRD patients. This bivariate analysis using the Spearman Rank correlation test. The results showed that respondents have high self-efficacy $(58.3 \%)$ and adherence to

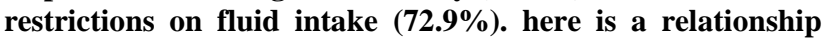
between self-efficacy and respondent adherence to fluid intake restrictions $(r=0.535, p$-value 0.000$)$, which means that the higher the self-efficacy, the higher the level of adherence to fluid intake restrictions and vice versa.Therefore nurses need to improve patient self-efficacy through providing education about the management of fluid restrictions in patients in all range of age.
\end{abstract}

Keywords-Seld-Efficacy, Adherence, Fluid Intake, Middle Adult, Hemodialysis

\section{INTRODUCTION}

End-Stage Renal Disease (ESRD) is the final stage of chronic kidney disease (CKD)which is characterized by permanent and irreversible kidney damage.As many as 98\% of ESRD sufferersundergo hemodialysis therapy [1]. An important part of hemodialysis (HD) is the adherence to fluid intake restrictions[2], which aims to prevent circulatory overload [3]. Some studies show that fluid restriction is difficult [4], also evoking psychological stress for patients[3]. Non-adherence to fluid restriction is a common problem in HD patients, it was found that about $69 \%$ of patients are non-adherencewith fluid intake restrictions[2].

Persistent non-adherence leads to the development of comorbidities such as cardiovascular disease, which account for up to $50 \%$ of deaths[5].

Al Islam Hospital Bandungas one of the referral hospitals in West Javarecorded that in six ESRD patients who underwent treatment between the time of dialysis, three patients were diagnosed with edema and pleural effusion, two patients had ascites while one patient was diagnosed with pulmonary TB. Based on interviews, information was obtained that almost all patients said they could not obey the programmed fluid restrictions. This is mainly due to thirst, especially when undergoing HD. Most patients feel unsure of being able to eradicate fluid intake.

One internal factor that contributes to adherenceto fluid intake restrictions is self-efficacy [6], which includes a positive attitudeand increasing patient perceptions of behavioral controlover adherence to fluid and dietary restrictions [7]. Age is one of the factors that influence self-efficacy[8]. Increasing age will also increase a person's ability to make decisions, think rationally, control emotions, be tolerant, and be more open to the views of others including his decision to follow therapeutic programs that have an impact on his health[9].

Research has found that older patients are more adherence to fluid intake restrictions[10]. However, other researchers found that there was no effect between the age of patients with adherenceto fluid intake restrictions[11].

\section{METHOD}

This study used quantitative research with a crosssectional design. This study aimed to identify the relationship of self-efficacy with adherence to fluid intake restrictions in hemodialysis patients in middle adulthood at Al Islam Hospital Bandung. The number of samples in 
this study 48 hemodialysis patients. The sampling technique was total sampling. Inclusion criteria include middle adulthood $\geq 40$ - $\leq 60$ years, hemodialysis 2 times a week, undergoing hemodialysis $\geq 5$ years. Exclusion criteria include respondents having decreased consciousness, having complications due to overloads such as edema, pleural effusion, and ascites. The study was conducted at the Hemodialysis Unit of Al Islam Hospital Bandung, in December 2019. This study was approved for passing the ethical test from the Ethics Research Committee of STIKes Aisyiyah Bandung with Number: 054/AKD/STIKes-AB/XII/2019.
Data collection tool using the selfefficacyinstrumentfrom previous researchers[12]. Adherence to fluid intake restrictionsuses the instrument of adoption from previous researchers to measure selfefficacy and adherence to fluid intake restrictionsin ESRD patients[13]. The univariate analysis aimed to describe the characteristics of respondentsconsisting of age, gender, education, employment, and history of hemodialysis. Bivariate analysis using Spearman Rank aimed to determine the relationship of self-efficacywith adherence in intake fluid restriction.

III. RESULT

TABLE I. CHARACTERISTICS OF RESPONDENT ( $\mathrm{N}=48$ )

\begin{tabular}{|c|c|c|}
\hline Characteristics of the respondent & Frequency (f) & Percentage $(\%)$ \\
\hline $\begin{array}{l}\text { Age } \\
\qquad \begin{array}{l}40-45 \text { years } \\
46-55 \text { years } \\
56-60 \text { years } \\
\end{array} \\
\end{array}$ & $\begin{array}{l}10 \\
13 \\
25\end{array}$ & $\begin{array}{l}20.8 \\
27.1 \\
52.1\end{array}$ \\
\hline $\begin{array}{ll}\text { Gender } & \\
& \text { Male } \\
& \text { Female }\end{array}$ & $\begin{array}{l}28 \\
20\end{array}$ & $\begin{array}{l}58.3 \\
41.7\end{array}$ \\
\hline $\begin{array}{l}\text { Education } \\
\qquad \begin{array}{l}\text { Primary school } \\
\text { Secondary school } \\
\text { High school } \\
\text { Colledge }\end{array}\end{array}$ & $\begin{array}{l}7 \\
8\end{array}$ & $\begin{array}{l}14.6 \\
16.7 \\
41.7 \\
27.1\end{array}$ \\
\hline $\begin{array}{l}\text { Employment } \\
\text { Employed } \\
\text { Unemployed }\end{array}$ & 6 & $\begin{array}{l}12.5 \\
87.5\end{array}$ \\
\hline $\begin{array}{l}\text { HD history } \\
\qquad \begin{array}{l}5-10 \text { years } \\
11 \text {-15years } 16-20 \text { years }\end{array}\end{array}$ & $\begin{array}{l}1 \\
1\end{array}$ & $\begin{array}{c}95.8 \\
2.1 \\
2.1 \\
\end{array}$ \\
\hline
\end{tabular}

Based on the table above shows that the majority of patients have undergone hemodialysis for 5-10 years $(95.8 \%)$, unemployed $(87.5 \%)$, more than half were male
$(58.3 \%)$, aged $56-60$ years $(52.1 \%)$, and less than half had high school education $(41.7 \%)$.

TABLE II. FREQUENCY DISTRIBUTIONSELF-EFFICACY(N=48)

\begin{tabular}{|c|c|c|}
\hline Self-efficacy & Frequency (f) & Percentage (\%) \\
\hline High & 28 & 58.3 \\
Moderate & 20 & 41.7 \\
Low & 0 & 0 \\
\hline
\end{tabular}

The table above shows that the majority of respondents have high self-efficacy $(58.3 \%)$.

TABLE III. FREQUENCY DISTRIBUTION RESPONDENT ADHERENCE ( $\mathrm{N}=48$ )

\begin{tabular}{|l|c|c|}
\hline Adherence & Frequency (f) & Percentage (\%) \\
\hline Adherent & 35 & 72.9 \\
Non-adherent & 13 & 27.1 \\
\hline
\end{tabular}

The table above shows that the majority of respondents (72.9\%) adhere to fluid restrictions.

TABLE IV. THE RELATIONSHIP BETWEEN SELF-EFFICACY TO ADHERENCE WITH FLUID RESTRICTION(N=48)

\begin{tabular}{|c|c|c|c|c|c|c|c|c|c|}
\hline & & \multicolumn{4}{|c|}{ Fluid Restriction } & \multirow{2}{*}{\multicolumn{2}{|c|}{ Total }} & \multirow{3}{*}{$r$} & \multirow{3}{*}{$p$-value } \\
\hline & & \multicolumn{2}{|c|}{ Adherent } & \multicolumn{2}{|c|}{ Non-adherent } & & & & \\
\hline & & $f$ & $\%$ & $f$ & $\%$ & $\mathrm{f}$ & $\%$ & & \\
\hline \multirow{2}{*}{$\begin{array}{c}\text { Self- } \\
\text { efficacy }\end{array}$} & Moderate & 9 & 18.8 & 11 & 22.9 & 20 & 41.7 & \multirow[t]{2}{*}{0.535} & \multirow[t]{2}{*}{0.000} \\
\hline & Low & 0 & 0 & 0 & 0 & 0 & 0 & & \\
\hline
\end{tabular}


The table above shows that most of the respondents have high self-efficacy with adherent as many as 26 respondents $(54.2 \%)$ and non-adherent as many as 2 respondents $(4.2 \%)$. Moderate self-efficacy with an adherent of 9 respondents $(18.8 \%)$ and non-adherent as many as 11 respondents (22.9\%). Spearman Rank statistical test results there is a relationship between selfefficacy and respondent adherence to fluid intake restrictions $(\mathrm{r}=0.535, \mathrm{p}<0.05)$.

\section{DISCUSSION}

The results of the study show that there was a relationship between self-efficacy and respondent adherence to fluid intake restrictions $(\mathrm{r}=0.535, \mathrm{p}<0.05)$. This is in line with a previous study that shows selfefficacy has a positive correlation with adherence to fluid intake restrictions[5]. The results of this study were supported by the majority of respondents having high selfefficacy $(58.3 \%)$ and adhering to fluid restrictions (72.9\%). Self-efficacy was one's assured success in doing self-care to achieve the desired result[14].High and low self-efficacy varies in each person, this is because it is influenced by several factors that influence in perceiving abilities in individuals. These factors are age, sex, education, and experience[15].

The results of the study found that the majority of respondents $(95.8 \%)$ had undergone hemodialysis for 5-10 years. This is in line with the previous study found that the longer HD duration was associated with a reduced risk of non-adherence to treatment. The reason may be that patients evaluate the effects of dialysis on their bodies and learn to cope with complications by talking to other patients and the healthcare staff [16].

Majority of respondent aged 56-60 years $(52,1 \%)$, this is in line with study found that individuals in the 20-39 year age group to experience morenon-adherent to treatment than the 40-59 year age group [17]although other study found there is no association with different categories of age and sex with adherence level [16], but it was found that younger male patients were at highest risk for non-adherence[18], it is similar that younger people were more non-adherent to the therapeutic regimen compared to their older age counterparts [19]. Young people are reported to experience intense feelings of being independent and therefore not wanting to accept being dependent on the HD machine and fluid restrictions[17]. It can be said that one of the factors that affect adherence to HD treatment is age [20].

This study founded that more than half of the respondents are men (58.3\%). This is not similarto another study that found the risk of non-adherence to HD treatment was found to be higher in men [16] women were more adherent to diet and fluid restriction than men [19].

This study found that respondent majority is unemployed. Previous study showed that employment status was found to be inversely related to fluid restriction adherence. These results suggested that subjects who were employed were more likely to be non-adherent to dietary and fluid restrictions [19].

Less than half of the respondents have a high school education. Some studies haveidentified a low level of education as a risk factor for non-adherence [16].In dialysis patients, knowledge has been associated with improved adherence[21]. This is similar to another study found that level of education affects adherence [19] even that understanding treatment instructions and the importance of treatment is probably relatively more important [16].

\section{CONCLUSIONS}

The results of this study indicate that there is a relationship between self-efficacy and respondent adherence to fluid intake restrictions $(\mathrm{r}=0.535, p$-value 0.000), which means that the higher the self-efficacy, the higher the level of adherence to fluid intake restrictions and vice versa. The closeness of the relationship is categorized as moderate $(0.4-<0.6)$, which means the closeness of the relationship of self-efficacy with adherence of middle-aged adult hemodialysis patients in adherence to fluid intake restrictions is moderate. Therefore nurses need to improve patient self-efficacy through providing education about the management of fluid restrictions in patients in all of age range.

\section{REFERENCES}

[1] Indonesian Renal Registry, "Program Indonesian Renal Registry," 2016. [Online]. Available: https://www.indonesianrenalregistry.org/ data/Indonesian Renal Registry 2016.pdf.

[2] N. Beerendrakumar, L. Ramamoorthy, and S. Haridasan, "Dietary and Fluid Regime Adherence in Chronic Kidney Disease Patients," J. Caring Sci., vol. 7 (1), pp. 17-20, 2018, doi: $10.15171 /$ jcs.2018.003

[3] L. F. Silva et al., "Coping With Fluid Restriction and the Quality of Life in Hemodialysis Patients With Very Low or No Daily Urine Output," Int J Artif Organs, vol. 37(6), pp. 427435, 2014, doi: 10.5301/ijao.5000329.

[4] F. B. Nerbass et al., "Perceptions of hemodialysis patients about dietary and fluid restrictions," Brazilian J. Nephrol., vol. 39(2), 2017, doi: 10.5935/0101-2800.20170031

[5] A. John, P. Alpert, J. Kawi, and R. Tandy, "The Relationship Between Self-Efficacy and Fluid and Dietary Compliance in Hemodialysis Patients," Clin. Sch. Rev., vol. 6(2), pp. 98-104, 2013, doi: http://dx.doi.org/10.1891/1939-2095.6.2.98.

[6] G. Chironda and B. Bhengu, "Contributing Factors to NonAdherence among Chronic Kidney Disease (CKD) Patients: A Systematic Review of Literature," Med. Clin. Rev., vol. 02(04), 2016, doi: https://doi.org/10.21767/2471-299X.1000038.

[7] D. Ficham, A. Kagee, and M. R. Moosa, "Dietary and fluid adherence among hemodialysis patients attending public sector hospital in the Western Cape.," South African J. Clin. Nutr., vol. 21(2), pp. 7-12., 2008.

[8] O. Okatiranti and F. Amelia, "Hubungan Self Efficacy dengan Perawatan Diri Lansia Hipertensi Studi Kasus: Salah Satu Puskesmas Di Kota Bandung," J. Keperawatan BSI, vol. 5(2), 2017.

[9] H. Nadi, N. Kurniawati, and H. Mariyanti, "Dukungan Sosial dan Motivasi Berhubungan dengan Kepatuhan Pembatasan Asupan Cairan pada Pasien Penyakit Ginjal Kronik yang Menjalani Hemodialisis.," Crit. Med. Surg. Nurs. J., vol. 6(2), 2019

[10] R. Tamie Nakao, R. Gorayeb, and J. A. Cardeal da Costa, "Factors Associated With Treatment Adherence of Brazilian Patients Undergoing Hemodialysis," Actual. En Psicol., vol. 30(121), pp. 77-90, 2016.

[11] U. Rizka, A. Istiningtyas, and E. Widiyastuti, "Hubungan SelfEfficacy Terhadap Kepatuhan Pembatasan Asupan Cairan pada Pasien GGK (Gagal Ginjal Kronik) yang Menjalani Hemodialisa Di RST Dr Asmir Salatiga," Stikes Kusuma Husada, 2017.

[12] A. Wakhid, E. L. Wijayanti, and L. Liyanovitasari, "Hubungan Efikasi Diri dengan Kualitas Hidup Pasien Gagal Ginjal Kronik 
yang Menjalani Hemodialisis," J. Holist. Nurs. Sci., vol. 5(2), pp. 56-63, 2018

[13] T. Hirmawaty, "Pengaruh Metode Pendidikan Kesehatan Individual terhadap Kepatuhan dalam Pembatasan Asupan Cairan pada Pasien Gagal Ginjal Kronik di RSUD Tarakan.," Universitas Esa Unggul, 2014.

[14] E. Yuliastuti and Suhartini, "Case Study: Awarding Education of Fluids Restriction Management on Impaired Kidney Perfusion for Improving Self-Efficacy of Patients and Families," Int. J. Nurs. Heal. Serv., vol. 1(1), pp. 49-59, 2018.

[15] A. Bandura, Self-efficacy. New York: Academic Press, 1994.

[16] N. OZEN, F. I. CINAR, D. ASKIN, and D. MUT, "Nonadherence in Hemodialysis Patients and Related Factors: A Multicenter Study," J. Nurs. Res., vol. 27(4), pp. 1-11, 2019, doi: doi.org/10.1097/jnr.0000000000000309.

[17] D. EFE and S. KOCAÖZ, "Adherence to diet and fluid restriction of individuals on hemodialysis treatment and affecting factors in Turkey," Japan J. Nurs. Sci., vol. 12, pp. 113-123, 2015, doi: 10.1111/jjns.12055.

[18] H. Beerappa and R. Chandrababu, "Adherence to dietary and fluid restrictions among patients undergoing hemodialysis: An observational study," Clin. Epidemiol. Glob. Heal., vol. 7, pp. 127-130, 2019.

[19] Y. M. Chan, M. S. Zalilah, and S. Z. Hii, "Determinants of Compliance Behaviours among Patients Undergoing Hemodialysis in Malaysia," PLoS One, vol. 7(8), pp. 1-7, 2012, doi: 10.1371/journal.pone.0041362.

[20] J. Kammerer, G. Garry, M. Hartigan, B. Carter, and L. Erlich, "Adherence in patients on dialysis: Strategies for success.," Nephrol. Nurs. J., vol. 34, pp. 479-486, 2007.

[21] K. Smith et al., "Patient Perspectives on Fluid Management in Chronic Hemodialysis," J. Ren. Nutr., vol. 20(5), pp. 334-341, 2010, doi: 10.1053/j.jrn.2009.09.001. 